\title{
Using Games as an Alternative Way of Teaching English Online
}

\author{
Giyatmi $^{*}$ \\ ${ }^{1}$ Prodi Pendidikan Bahasa Inggris, Universitas Veteran Bangun Nusantara Sukoharjo \\ *giyatmi85jimmy@gmail.com
}

\begin{abstract}
Covid-19 pandemic has shifted face-to-face learning into the online one. This shift gives impact to teachers, students, and parents. Most of the problems face by both teachers and students are the internet connection and technological mastery dealing with online learning. Besides, online learning also gives impact on the students' psychological condition. Online learning might also cause pupils to feel frustrated, tired, and idle faster. Furthermore, online learning causes pupils to become easily distracted and frustrated as a result of the quantity of responsibilities assigned by teachers. The teachers should find alternative ways to make online learning more attractive and motivate the students. One of them is using game during online learning or known as game-based learning. There are many game applications that the teacher can use in their online classroom, such as Kahoot, Wordwall, Quizwhizzer, www.learningapps.org, www.liveworksheet.com, www.flippity.net etc. Teachers can create games with those application, even teachers can create worksheet too. Teachers are supposed to get trained on how to make distance learning experience more interactive and the students get motivated.
\end{abstract}

Key words: Covid-19 pandemic, game application, game-based learning, online learning, teaching English.

\section{Introduction}

COVID-19 pandemic has shifted the previously face-to-face learning into the online one. Online learning is actually not something new in education. Online learning is growing rapidly with advances in information technology, especially the internet. But actually this online learning can be traced back to the first time in 1960 (even when the internet was not yet invented) at the University of Illinois, USA. At that time students learn from computers that are connected to form networks. Later in 1980, online classes were offered at the University of Toronto. In 1989, the University of Phoenix became the first educational institution offering online learning both bachelor and master degrees. Meanwhile, in 1990, The Open University of Britain started to hold distance learning for the first time [1].

Meanwhile, in Indonesia online learning is also not something new actually. Online learning in Indonesia has been pioneered since the 1980 s and developed rapidly in the 2000 s. However, it seems that not many educational units in Indonesia are implementing online learning. This online learning found its momentum in early 2020, with the Covid-19 Pandemic. This pandemic has forced all educational units in various parts of the world to implement online learning activities.

Online learning is the best alternative and solution. According to Reimers in [2], online learning is a very helpful medium in overcoming the issues of the world of education during the COVID-19 pandemic. Online Learning is a part 
of distance learning. It is broadly learning through media and electronic technology, so some call online learning as e-learning. Online learning uses a lot of information and communication technology in its implementation [3]. Online learning is carried out by utilizing internet technology so that it can be carried out anywhere and anytime. Mastery of technologies, especially those related to computer competencies and internet by teachers and students are important things in online learning [4].

For students, mastering computer skills and internet is not something that is difficult. They are digital natives which were born at the same time as the existence of the technology. They grow and develop with the technology. However, the opposite thing happens with the teachers (the digital immigrants) who were born before the technology appeared. Mastering computer and internet skills become a new challenge for teachers. Teachers have to try hard to be able to adapt to the generation they are teaching now [5].

Perhaps, there are still many teachers who are reluctant or delaying to improve their ability in terms of mastering technology in education before the Covid-19 Pandemic. Previous learning style which was less in contact with computers and internet has contributed to the teachers' reluctances on using technology in teaching and learning activities. However, with Covid-19 Pandemic, like it or not, teachers have to start learning things related to online learning such as learning platforms (Google Classroom, Edmodo, Moodle, Canva), searching for teaching materials on Youtube, making learning media such as learning videos, etc.

Applying online learning during Covid-19 pandemic is not an easy thing since there are many obstacles, pros and cons. However, online learning is the only best solution during the Covid-19 Pandemic. With online learning, education can still run and the spreading of the virus can also be reduced. During Covid-19 Pandemic, transferring face-to-face learning to online one, particularly for teaching English is also a beneficial technique [4].

The transformation of face-to-face classroom to online classroom causes some problems [6]. Many studies discuss views and perceptions related to online learning during the Covid-19 pandemic, from teachers, students and parents. Parents' inability to provide gadgets such as laptops, computers and smartphones which are indispensable in online learning contributes to the lack of online learning [6]. Lack of learning equipment gives problems to the students in online learning. The common challenge faced by both teachers and students during online learning is internet connection. Online learning is widely dependent on internet technology, so a good internet connection will affect the smooth implementation of online learning. Internet accessibility is highly needed during online learning [4]. Many students and teachers complain about the unstable internet connection and extra cost for quota during online learning during the Pandemic [3]. The study finds that one of the 3 main problems faced during online learning is availability and sustainability of internet connection [7]. Poor internet connection results in students' inability to access the teaching media such as zoom meeting [6]. In addition, other problem faced by teachers and students during online learning is the mastery of technology in learning. To ensure that learning runs smoothly, both teachers and students must comprehend the use of technology, particularly learning technology and learning applications.

Online learning is closely related to information and communication technology, in fact there are still many teachers who have not mastered technology in teaching. Teachers and students are required to have skills in technology to teach online [4]. They must be ready to apply technology in their respective institutions. In addition, in 4.0 era, it is a must for the teachers to master the internet and technology in teaching [6]. Technological development in the 4.0 era helps the implementation of online learning in the case offering conveniences for teachers in the teaching process. However, not all teachers have the maximum skills needed in online teaching. The difference of teachers and students' mastery of technology can create a gap between them [4]. Most nowadays' students have no difficulties in operating learning application, managing their gadget to study during online learning. Therefore, some teachers still need to improve their skill in technology during teaching and learning process such as exploring learning application, managing their gadget, and creating teaching material or teaching media.

Teachers play an important role in online learning since they are the ones who control the learning process. E-learning as a distant learning medium introduces a new paradigm, notably the role of professors as "facilitators" and students as "active participants" in the teaching and learning process. As a result, teachers must develop effective teaching approaches and deliver engaging teaching materials, while students must actively participate in the learning process [8] The teacher must be able to create an attractive online learning so that the students feel comfortable. According to Dhawan in [2], online learning might also cause pupils to feel frustrated, tired, and idle faster. Online learning causes pupils to become easily distracted and frustrated as a result of the quantity of responsibilities assigned by teachers [9]. Meanwhile, Syahputri et al in [9], mention that there are seven mental impacts caused by exposing their gadget screen, including weariness, physical pain (headache, shoulder afternoon, eyes afternoon), poor management time, feelings of isolation, and ambiguity about teachers' explanations. Teachers are supposed to get trained on how to make distance learning experience more interactive. In addition, the students get motivated during the online learning.

One alternative to make online learning more interesting can be done by the use of games during online learning. It, hopefully, can help the students not to get bored easily and get motivated. The use of games in learning is actually very common in face-to-face learning. The use of game in the context of e-learning trends is game-based learning (Beetham in Doney)[10]. In line with the opinion, the use of a game to enhance the learning process is known as game-based learning. Meanwhile, digital game-based learning or mobile game-based learning is a sort of game in 
which the operation is carried out using digital devices [11]. Perhaps, we are now familiar with gamification. The application of gaming aspects in non-entertainment contexts to improve learning is known as gamification [12]

The game is appealing for both children and adults. Furthermore, it has a tremendous influence on their way of life [12]. The benefit of mobile game learning can be seen from technological perspective in which most students choose to utilize their mobile devices. Furthermore, from pedagogical perspective, the use of mobile game learning in online teaching and learning can increase the students' motivation to learn and improve their learning outcomes [13]. Digital game-based learning can increase learning motivation and student involvement in the learning process, as well as improve students' learning outcomes and activities [10]. Games-based learning that are commonly applied in online learning are Kahoot, Quizziz, Wordwall. There are several studies mentioning that Kahoot improve the students' motivation and their learning outcomes [14]. Another study finds that the students become more motivated in online learning with Quizziz 15]

In this article, the writer would like to share ideas of teaching English online using game-based learning. They, hopefully, can be interesting ways to teach online, so that the students will not feel bored instead of they can get motivated. The writer hopes that this article will be useful for teachers in elementary, junior high, and high school to teach during Covid-19 Pandemic especially teaching English.

\section{Theoretical Reviews}

\section{Game Applications in English Online Learnig}

There are a lot of applications that we can use to teach English online in an interesting way such as Kahoot, Wordwall and Quizwhizzer. The teachers can create a game by collaborating Google Sheet with games on www.flippity.net. The teachers can create worksheet via www.liveworksheet.com then share it via Google Classroom as the assignment. In addition, the teacher can use www.learningapps.org to create a simple game.

\section{Kahoot!}

Kahoot is a quiz-based learning software that makes learning enjoyable. Kahoot! is a free online game that is both fun and social for students and teachers, allowing them to engage both physically and digitally. Kahoot can be accessed easily with browser on a computer, laptop, tablet, and smartphone.

To access Kahoot, the teachers just need to register. They can create their own games or use the games available on Kahoot. There are more than 40 million games that can be accessed easily. After that the teachers just need to share the PIN for playing or assigning the game for the students in the class. There is a leaderboard in Kahoot. Leaderboard in the video game is frequently used to denote rank among those who play in the game. When the students play the game, the teachers can see the leaderboard so that they can see the movements of the students. In addition, there is a podium too, so students and teachers can know who the winners are. Here is the link of Kahoot tutorial example from You Tube, https://www.youtube.com/watch?v=sqf8ovpjnYo[16]

The writer sometimes uses Kahoot to teach in the class. The writer usually creates a multiple choice quiz dealing with the material. The following is example of quiz with Kahoot that the writer ever tries in the class. The writer used this quiz for Introduction to Linguistics course.

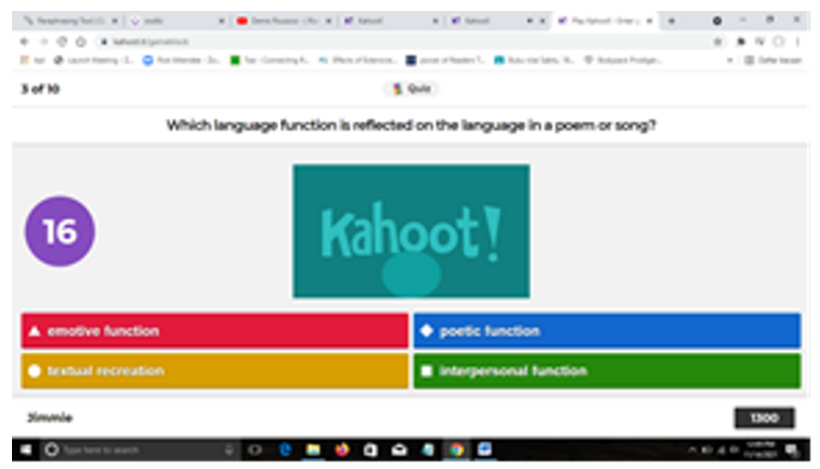

Figure 1. Kahoot!

\section{Wordwall}

Wordwall is a web-based program that allows teachers to create entertaining activity during the learning process. Wordwall can be used to create interactive and printable activities like multiple-choice, grouping, and matching. 
There are many templates that the teachers can choose, however, we may only use up to six for free. The interactive games can be accessed with device, such as a computer, tablet, phone, or interactive whiteboard.

Just like Kahoot, to access wordwall, teachers need to register to get an account. Once teachers produced an activity, teachers can distribute it in a variety of ways: such as a URL, or web address to access it. Even teachers can attach it in the school online platform and give the students a code to access it through the www.wordwall.net. There is also a leaderboard on wordwall, so we can see the rank of the students.

Here is the link of tutorial of how to access wordwall https://www.youtube.com/watch?v=0Uwmwl5JuLs\&t=352s [17]. The following is the example of game on wordwall that the writer uses in teaching Morphology. The writer uses Maze Chase game.

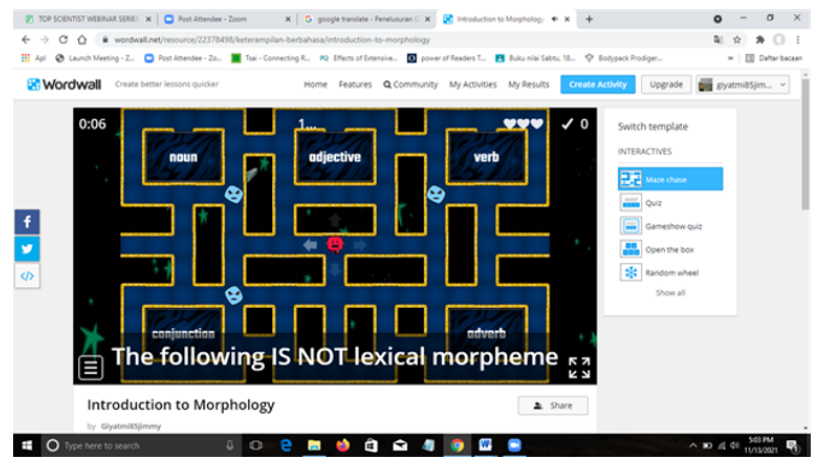

Figure 2. Wordwall

\section{Liveworksheet}

This platform allows teachers to transform traditional paper worksheets into interactive online worksheets with self-correction. Students can do the worksheets online, and they can see their score immediately after completing the activity. The pupils can then submit their answers to the teacher. This benefits students (it motivates them), teachers (it saves them time), and the environment (it saves paper).

To access www.liveworksheet.com, the teachers need to register to get an account. The teacher can create their own worksheet or can use the available ones on the website. After that the teacher need to share the link to the students. Even, the link can be shared via Google Classroom and set up as an assignment. There are many tutorials of creating interactive worksheet and uploading it in www.liveworksheet.com.

Here are the examples of worksheets that the writer has created for the English online learning; https://www.liveworksheets.com/al2594337gy (The worksheet is about verbal and nominal sentence), https://www.liveworksheets.com/rb2597962nv (This worksheet is used to teach Introduction to Linguistics), and https://www.liveworksheets.com/xm2556493ci (This worksheet is for teaching Business English Writing).

After sharing the links via Google Classroom, the writer asked the students to finish the worksheet. Having completed the worksheet, the students can find out their score right away and finally they have to upload the screen shoot of their score in Google Classroom.

\section{Learningapps}

LearningApps.org is a free web platform that allows teachers to create a variety of online learning activities such as matching, fill-in-the-blanks, word grids (word search) and crossword puzzles, maps, voting, and sorting. The platform contains templates for the most of basic jobs, as well as some novel templates with gamification elements.

The teachers need to create an account by having a registration first. This platform allows the teachers to create various apps for their learning purposes and share them with other teachers who may use the apps or adapt them to match their own teaching aims. One of the best aspects about LearningApps.org is that it is entirely free. The writer creates some apps that match with the material given such as the following: https://learningapps.org/watch?v=ps288h2m521( this link deals with matching English Proverb with their meaning), https://learningapps.org/watch? $v=$ pj191gbs321 (this link is about matching Indonesian and English proverbs with similar meanings), https://learningapps.org/watch? $v=p m k d k 150 a 21$ ( the students have to rearrange the scramble sentence into a good order of Sales Letter), and https://learningapps.org/watch? $v=p 6 w 154 g k 521$ (the students have to put the Business Call dialog into a good order).

\section{Collaboration of Google Sheet and Flippity}

Flippity is a free website that converts Google spreadsheets into interactive digital manipulatives, games, and tools. The teacher can create games by collaborating www.flippity.net with Google Sheet. There are many games that the 
teachers can access such as flashcard, random name picker, bingo, board game, matching pair, etc. Here is the link for making games with flippity https://www.youtube.com/watch? $v=D y E V Q s b l Y F 8$ [18]. The teacher can access the games freely then publish the games on Google Sheet. After getting the game link, the teachers can share the link to the students in the classroom. Teachers can use the game for teaching English. The writer uses Matching Game to teach Morphology. The writer asks the students to match the words and their affixes. The students just open the cards then try to find the matching pairs. When they are matched, there will be green outline in the card and then the cards disappear. The following is the example of the matching game. The writer created this game for teaching affixes in Morphology. The students have to find cards with affix and the word with that affix such as -or on Translator. When they matched there will be green light and when the students click the cards, they disappeared. They students have to find it fast because there is a counter on the game. The following is the example of the game.

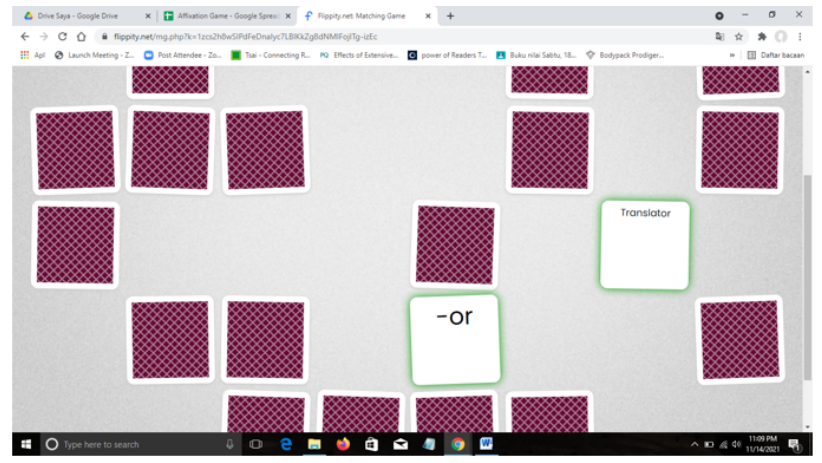

Figure 3. Matching Game on Flippity

\section{Quizwhizzer}

QuizWhizzer is a quiz maker that sends participants racing on a track of your choosing. Here is the link of Quizwhizzer tutorial $h t t p s: / / w w w . y o u t u b e . c o m / w a t c h ? v=5 J N 5 i C 14 y d g$ [19]. Quizzes support up to 30 participants who can access the game from any device by entering a unique access code. You can also run multiple quizzes at the same time. When the game is over, teachers can download the result of the game in a spreadsheet with the names of the players and the results of each question. As a kind of game, there is a leaderboard too in Quizwhizzer. Here is the example of game in Quizwhizzer that the writer shares in the classroom. The game is about English Modal Verbs. The students have to answer several questions about modal during the game.

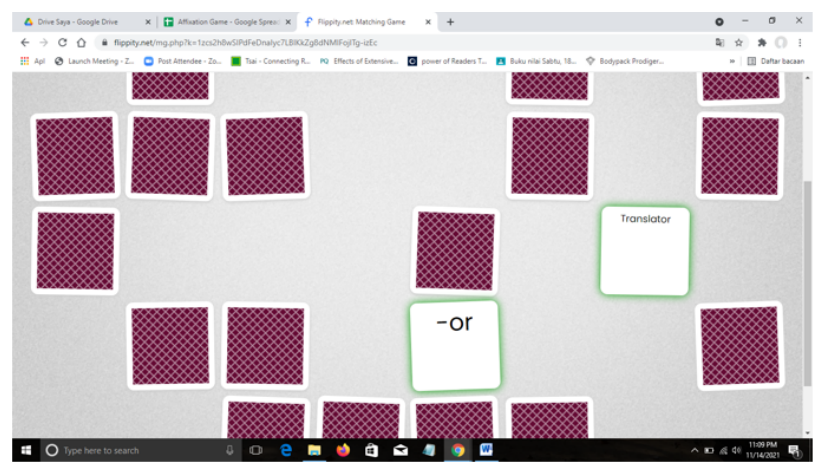

Figure 4. Quizwhizzer

\section{Conclusion}

Teachers play an important role in the implementation of online learning during the covid-19 pandemic. Teachers are expected to create interesting and fun online learning so that students are motivated, excited and not easily bored. Teachers need to improve their technological mastery in teaching and learning process. As teachers, we should not feel too late to study about internet technology like game applications that can be used in teaching. Even, teachers should not be ashamed to ask about it to their students about it because they are more technology literate than we 
are. There are many game applications for learning such as Kahoot!, Wordwall, Quizwhisser, Learningapps, Flippity and Liveworksheet that can be applied in the classroom. Teachers can study the game application by watching video tutorials on Youtube. Teachers also need to practice alone or together in workshops related to game applications in learning. Even if, someday, learning will be normal (back to face-to-face learning), the teachers can still use this application during the learning.

\section{Acknowledgements}

The writer would like to thank her institution, Veteran Bangun Nusantara University of Sukoharjo that has provided the financial support for her to join this international conference. The writer also would like to show her gratitude to the committee of the 6 th.

\section{References}

[1] S. Sarkar, "A brief history of online education," Adamas University, 16-May-2020. [Online]. Available: https : //adamasuniversity.ac.in/a-brief-history-of-online-education/. [Accessed: 20-Nov-2021].

[2] J. P. S, "Students' Problems Face In Online Learning Amidt Pandemic Covid-19," Acitya: Journal of Teaching \& Education, vol. 3, pp. 188-197, 2021.

[3] L. R. Amir, I. Tanti, D. A. Maharani, Y. S. Wimardhani, V. Julia, B. Sulijaya, and R. Puspitawati, "Student perspective of classroom and distance learning during COVID-19 pandemic in the Undergraduate Dental Study Program Universitas Indonesia," BMC Medical Education, vol. 20, no. 1, 2020.

[4] H. Rifiyanti, "Learners' Perceptions of Online English Learning during COVID-19 Pandemic," SCOPE Journal of English Language Teaching, vol. 5, no. 1, pp. 31-35, Sep. 2020.

[5] M. Mualim, W. D. Marfuah, and E. Sartika, "The Strengths and Pitfalls of Google Classroom Application to Gen-Z Students' Learning Hybridity," in International Conference on Islamic Education: Challenges in Technology and Literacy, vol. 4.

[6] S. Ariani and T. Tawali, "Problems of online learning during covid-19 pandemic in speaking for professional context class," Jo-ELT (Journal of English Language Teaching) Fakultas Pendidikan Bahasa \& Seni Prodi Pendidikan Bahasa Inggris IKIP, vol. 8, no. 1, p. 32, 2021

[7] A. S. Agung, M. W. Surtikanti, and C. A. Q. , OP, "Students' Perception of Online Learning during COVID19 Pandemic: A Case Study on the English Students of STKIP Pamane Talino," Journal of Social Sciences and Humanities, vol. 10, no. 2, pp. 225-235, 2020.

[8] F. Fahmalatif, A. Purwanto, E. Siswanto, and J. Andriyanto, "Exploring Barriers and Solutions of Online Learning During the Covid-19 Pandemic By Vocational School Teachers," Journal of Industrial Engineering \& Management Research, vol. 2, no. 2, pp. 53-63

[9] I. Yuzulia, "The Challenges Of Online Learning During Pandemic: Students' Voice," Wanastra: Jurnal Bahasa dan Sastra, vol. 12, no. 1, 2020

[10] I. Doney, "Research into effective gamification features to inform E-learning design," Research in Learning Technology, vol. 27, pp. 1-17, 2019

[11] I. F. Wati and Yunaiwatika, " 1st International Conference On Information Technology And Education (ICITE 2020)," in Digital Game-Based Learning as A Solution to Fun Learning Challenges During the Covid-19 Pandemic, 2020, pp. 202-210.

[12] F. A. Nieto-Escamez and M. D. Roldán-Tapia, "Gamification as online teaching strategy during COVID-19: A mini-review," Frontiers in Psychology, vol. 12, 2021.

[13] A. Krouska, C. Troussas, and C. Sgouropoulou, "Mobile game-based learning as a solution in COVID-19 ERA: Modeling the pedagogical affordance and student interactions," Education and Information Technologies, 2021

[14] M. Martín-Sómer, J. Moreira, and C. Casado, "Use of Kahoot! to keep students' motivation during online classes in the lockdown period caused by covid 19," Education for Chemical Engineers, vol. 36, pp. 154-159, 2021.

[15] N. Safarati and R. Rahma, "The effectiveness of online learning using Quizizz Education Game Media during the COVID-19 pandemic in Applied Physics Courses," Indonesian Review of Physics, vol. 3, no. 2, p. 52, 2020. 
[16] "Tutorial Lengkap kahoot! Belajar online menyenangkan - youtube." [Online]. Available: https : //www . youtube . $\mathrm{com} /$ watch?v=sqf 8ovpjnYo. [Accessed: 20-Nov-2021].

[17] "Cara Membuat Quiz Menggunakan Wordwall," 10-Jun-2020. [Online]. Available: https://www . youtube.com/ watch?v=DyEVQsblYF8. [Accessed: 20-Nov-2021]

[18] "Flippity Tutorial," 29-Nov-2020. [Online]. Available: https ://www . youtube . com/watch?v=DyEVQsb1YF8. [Accessed: 20-Nov-2021]

[19] "Cara membuat soal menggunakan quizwhizzer - youtube," 08-Jul-202AD. [Online]. Available: https: //www . youtube . com/watch?v=5JN5iC14ydg. [Accessed: 20-Nov-2021] 